\title{
RUINY ARCHITEKTURY SAKRALNEJ. ŚMIERĆ MIEJSCA - ŚMIERĆ SACRUM?
}

Ruina to siedziba życia, którą życie opuściło (...) stanowi obecna, teraźniejsza forme przeszłego życia, nie treści albo resztek życia, ale jego przeszłości, przemijalności ${ }^{1}$.

Materia poprzez poświęcenie nabiera nowych właściwości, właściwości duchowych. Staje się cząstką innego świata².

Witold P. Glinkowski w Transcendencjach codzienności pisze, że ilekroć człowiek jest, tylekroć przebywa w jakimś miejscu. Ale również je porzuca, oddala się, „bytuje ku innemu miejscu”. Każde miejsce żyje zatem swoim rytmem, to znaczy rodzi się, dojrzewa, starzeje się i umiera, odchodząc w niebyt i w niepamięć ${ }^{3}$. Pojęcie „śmierci” kojarzy się przede wszystkim z nazywaniem najważniejszej dla człowieka formy skończoności. Służy często jako metafora końca życia, jest tym, co zmienia jego naturalny porządek. Śmierć jest przede wszystkim pewną realną oczywistością, z którą musimy się oswoićt ${ }^{4}$ We wstępie książki Miasto i sacrum odnajdujemy niezwykle

${ }^{1}$ G. Simmel, Ruina. Próba estetyczna, [w:] tenże, Most i drzwi. Wybór esejów, przeł. M. Łukasiewicz, Oficyna Naukowa, Warszawa 2006, s. 175.

${ }^{2}$ H. Paprocki, Sacrum i profanum: nadzieje i zagrożenia, [w:] M Lipińska (red)., Sacrum i profanum a wspótczesna kultura, Warszawa 2006, s. 64.

${ }^{3}$ W.P. Glinkowski, Transcendencje codzienności. Miejsca, spotkania, obsesje, Tygiel Kultury, Łódź 2008, s. 16-17, 164.

${ }^{4}$ Por. M. Bonowska, Przemijanie: śmierć, pogrzeb i życie pozagrobowe w wyobrażeniach mieszkańców Pomorza Zachodniego na przełomie XIX i XX wieku, Eco, Poznań 2004, s. 9-10. Na temat 
ważną wątpliwość. Anna Królikowska i Maciej Kowalewski zadają bowiem pytanie o to, czy sacrum miejsc w ogóle można poddać naukowej analizie i czy takie pojęcia, jak „przestrzeń święta” czy sacrum dają się w jakiś sposób operacjonalizować oraz czy jest możliwe rozstrzyganie w sposób obiektywny o świętości przestrzeni ${ }^{5}$. Powyższe stwierdzenia i wątpliwości stanowią dla mnie punkt wyjścia do rozważań na temat miejsc sakralnych, zrujnowanych, opuszczonych i zapomnianych przez człowieka. Artykuł podejmuje kwestię statusu ruiny obiektu sakralnego jako miejsca nie-miejsca i zaniku sfery sacrum definiującej niegdyś to miejsce. Określenie ruiny nie-miejscem wynika z fenomenologicznego definiowania miejsca jako pewnego punktu w przestrzeni, posiadającego szczególną tożsamość nadaną mu przez bytującego w nim w sposób różnorodny człowieka. Człowiek bowiem, jak chciałby Glinkowski, zawsze jest u-miejscowiony, gdyż to właśnie miejsca, codzienne i niecodzienne, określają jego egzystencję. Pojawia się jednak pytanie, czy ta zależność jest istotna również w wypadku samego miejsca; czy miejsce pozostaje miejscem, gdy człowiek ostatecznie je opuści, gdy przestanie ono być obecne w jego codziennym doświadczeniu?

Fenomenologiczny punkt widzenia kieruje naszą uwagę przede wszystkim na wzajemną zależność miejsca i człowieka. Hanna Buczyńska-Garewicz podkreśla przecież, że ani miejsce, ani ludzie $\mathrm{w}$ nim przebywający, nie są „pierwsze wobec drugiego". Istotę obu stanowi bowiem wzajemne współistnienie i współformowanie. Ludzie żyją w miejscach i poprzez miejsca, podobnie jak miejsca istnieją dzięki człowiekowi ${ }^{6}$. Wydaje się zatem, że ruiny, w tym również sakralne, jako miejsca opuszczone przez człowieka tracą w większości aspekt miejsca antropologicznego i stają się przede wszystkim punktami na miejskiej mapie. Zapomniane, pozbawione ludzkiego bytowania i doświadczenia obecności Boga, same stają się dla siebie przyczyną bycia czy, jak chciałby Tadeusz Sławek, "wy-miejscawiają się", stają się miejscami bez miejsca7 ${ }^{7}$ Na podobną zależność zwracają również uwagę socjologowie:

Co to znaczy, że przestrzeń jest święta? Dla socjologów badających miasto, odpowiedź może być następująca: świętość przestrzeni powstaje dzięki znaczeniom zbiorowym,

śmierci oswojonej zob. Ph. Ariès, Rozważania o historii śmierci, Oficyna Naukowa, Warszawa 2007 oraz tenże, Pięć wariacji na cztery tematy, [w:] Antropologia śmierci. Myśl francuska, wybór i przeł. S. Cichowicz i J. M. Godzimirski, Wydawnictwo Naukowe PWN, Warszawa 1993.

5 A.M. Królikowska, M. Kowalewski, W poszukiwaniu przestrzeni świętej w mieście, [w:] M. Kowalewski, A.M. Królikowska (red.), Miasto i sacrum, NOMOS, Kraków 2011, s. 9.

${ }^{6}$ H. Buczyńska-Garewicz, Miejsca, strony, okolice. Przyczynek do fenomenologii przestrzeni, Universitas, Kraków 2006, s. 5-6.

7 T. Sławek, Miasto zapomniane przez Boga i ludzi i fragment z Horacego, [w:] Z. Kadłubek (red.), Genius loci. Studia o człowieku w przestrzeni, Wydawnictwo FA-art, Katowice 2007, s. 80. 
które są jej przypisywane. Bez tych znaczeń byłaby tylko subiektywną przestrzenią indywidualną albo obiektywną kategorią ulokowaną poza światem społecznym i przez to poza obszarem dociekań socjologów ${ }^{8}$.

Podobnie jak kwestia „u-miejscowienia” ruiny w codziennym doświadczeniu człowieka, również status sacrum jest problematyczny. Poniższe rozważania dotyczą współczesnego statusu zrujnowanych kościołów i katedr chrześcijańskich, dlatego sacrum definiowane jest tu jako miejsce hierofanii, „uobecnianie Boga”, „Bożego Ducha”, sfera dostępu do Absolutu, która, aby zaistnieć, potrzebuje świadków ${ }^{9}$. Z biegiem czasu, wraz z postępującą sekularyzacją i laicyzacją społeczeństw ${ }^{10}$, to, co święte, przestało być wszechobecne i wszechogarniające. Sacrum staje się współcześnie „własnością fragmentów przestrzeni", próbuje mu się bowiem przypisać widzialne granice, jest zamykane w enklawach, ograniczane i poddawane swoistej kontroli. Jedną z takich enklaw jest oczywiście chrześcijańska świątynia, która od wieków stanowi „miejsce Bożej Obecności”, „bramy do nieba” oraz „doświadczenia ofiary Chrystusa". Miejsca przeznaczone na świątynię nigdy nie były przecież dowolnie wybierane, lecz odkrywane i w ten sposób wpisywane w porządek świata / miasta:

Są rodzaje sacrum, które czują się w mieście pewniej. W sposób podstawowy tkankę sakralną w miastach Europy odnajdujemy w ich kościołach. To sacrum zalegalizowane, trwale osadzone i wmontowane w strukturę społeczną miasta. (...) to sacrum ujęte $\mathrm{w}$ formuły religii instytucjonalnej po prostu trwa, reprodukuje się, mając swoich kapłanów i rzeczników ${ }^{11}$.

Obiekty sakralne są wygenerowanym, wielowymiarowym obrazem miejsca sacrum i stanowią ramy przestrzenne dla stałej Obecności, która, jak pisze Ewa Cisek, jest ponadczasowa i zapewnia lokalnej społeczności poczu-

${ }^{8}$ M. Kowalewski, D. Kowalewska, Katedra jako stereotyp przestrzenny. Przypadek kościoła pw. Św. Jakuba w Szczecinie, [w:] M. Kowalewski, A.M. Królikowska (red.), Miasto i sacrum, dz. cyt., s. 75.

${ }^{9}$ Na takie znaczenie sacrum i wartości sakralnych zwraca uwagę m.in. A. Grzegorczyk (Uobecnianie wartości sakralnych w kulturze miasta, [w:] E. Rewers, A. Skórzyńska (red.), Sztuka kapitat kulturowy polskich miast, Wydawnictwo Naukowe UAM, Poznań 2010, s. 57). Należy jednak zwrócić uwagę na sam problem definiowania sacrum, jak czyni to chociażby Bogna Kietlińska, gdy podkreśla ambiwalencję tego pojęcia. Łacińskie sacer oznaczało bowiem zarówno to, co święte, jak i to, co przeklęte. Autorka wskazuje na nieostrość i pojemność tego pojęcia, które, chociaż definiowane już przez takich klasyków jak Friedrich Schleiermacher, Émile Durkheim, Rudolf Otto, Mircea Eliade, czy Roger Callois, wciąż wymyka się jednoznacznym próbom uściślenia. Zob. B. Kietlińska, Przeklęte sacrum, [w:] M. Kowalewski, A.M. Królikowska (red.), Miasto i sacrum, dz. cyt., s. 250.

${ }^{10}$ Na ten temat zob. również: J. Baniak, Desakralizacja kultu religijnego i świąt religijnych w Polsce, NOMOS, Kraków 2007, s. 26-31.

11 A.M. Królikowska, M. Kowalewski, W poszukiwaniu..., dz. cyt., s. 11-12. 
cie przynależności, tożsamości i bezpieczeństwa ${ }^{12}$. Pojawia się zatem pytanie, czy opuszczony kościół to jeszcze przestrzeń sacrum, czy też profanacja, którą mimo wszystko należy zachować. Pozostaje bowiem kwestia sposobu, $\mathrm{w}$ jaki ruina sakralna wpisuje się w porządek miasta, który niegdyś formowała. Opuszczona świątynia to przecież, obiektywnie rzecz ujmując, „martwe miejsce", w którym nie ma już żadnej aktywności ludzkiej związanej ze sferą sacrum, w którym zanikło zbiorowe i indywidualne doświadczenie Obecności. Jak w przypadku wszystkich zrujnowanych budynków, stanowi ona swoisty odpad, niszczący estetykę współczesnych środowisk miejskich. Ruiny traktowane są bowiem najczęściej jako przestrzeń zbędna, negatywna, wprowadzająca element chaosu i wywołująca anty-społeczne działania ${ }^{13}$. Leon Dyczewski natomiast definiuje sacrum jako coś, co jest ściśle związane z ludźmi, bez których nie istnieje; "lokuje się zawsze tam, gdzie są ludzie"14. Berthold Burkhardt podkreśla, że zniszczone kościoły w środku miast i wsi symbolizują pustkę i niemal zawsze prowadzą do różnych zmian w ich bezpośrednim otoczeniu. Miejsce kultu, nawet po narastającej sekularyzacji i laicyzacji, często nadal zajmuje miejsce centralne $\mathrm{w}$ tkance miasta lub $\mathrm{wsi}^{15}$. Świętość zniszczonego miejsca dla wielu przestaje być jednak oczywista. Jak czytamy w Miejscach, stronach i okolicach, katedry pozostawione w zapomnieniu schodzą do pozycji rzeczy fizycznych i stają się jedynie masą kamieni. Miejsce konstytuuje się bowiem w przeżyciu, dlatego wymaga określonych doświadczeń, aby ,jego treść mogła wyjść na jaw i jego intencjonalny byt zachował swą obecność"16. Podkreśla to również Detlef Karg, gdy pisze:

(...) budowle kościelne fascynują nas, przyciągają uwagę i porywają przede wszystkim dlatego, że przekazują wyśniony i kolektywnie przeżywany obraz świata. Może właśnie dlatego ludzie przychodzą do nich, również bezwyznaniowcy, w poszukiwaniu wartości i religijności nie tylko podczas rytualnych uroczystości w czasie ważnych świąt kościelnych. Również człowiek nie wyznający żadnej religii angażuje się w utrzymanie kościołów, kiedy istnieje niebezpieczeństwo, że znikną one z panoramy miast, wsi czy też krajobrazu ${ }^{17}$.

12 E. Cisek, Norweskie katedry jako przykład na nowo konstruowanej przestrzeni sacrum, Biblioteka Cyfrowa Politechniki Krakowskiej, <http://suw.biblos.pk.edu.pl/resources/i5/i5/i4/i8/ r5548/CisekE_NorweskieKatedry.pdf > [dostęp: 15.04.2012].

13 Por. T. Edensor, Industrial Ruins. Spaces, Aesthetics and Materiality, Bloomsbury Academic, New York 2005.

${ }^{14}$ L. Dyczewski, Wyganiane sacrum powraca, [w:] M. Kowalewski, A.M. Królikowska (red.), Miasto i sacrum, dz. cyt., s. 259.

15 B. Burkhardt, Stosunek do ruin kościotów, [w:] Ruiny zabytków sakralnych: ochrona i adaptacja do nowych funkcji, przeł. A. Grzybkowska, E. Bagłajewska-Miglus, Fundacja „Fara Gubińska Centrum Spotkań Polsko-Niemieckich", Gubin 2008, s. 37.

${ }^{16}$ H. Buczyńska-Garewicz, Miejsca, strony, okolice..., dz. cyt., s. 33.

17 D. Karg, Określenie miejsca - ruiny kościołów jako profanacja, która należy zachować?, [w:] Ruiny zabytków sakralnych..., dz. cyt., s. 14. 
Ze względu na określenia tych budowli jako miejsc poświęconych, świętych i godnych, żaden budynek sakralny nie powinien teoretycznie ulec jakiejkolwiek profanacji. Opuszczone kościoły jednak się wyburza lub adaptuje do zupełnie nowych funkcji, przekształcając budowle sakralne w supermarkety, kluby, czy „świątynie sztuki”. Jan Kurek nazywa to wprost „laicyzacją sacrum", jego "komercyjną transformacją" ${ }^{18}$. Jako przykład takiego działania mogą służyć dwa niemieckie kościoły: św. Rafaela Archanioła, wybudowany w latach 1959-1965 w berlińskiej dzielnicy Gatow, zburzony w 2005 roku ( $w$ tym miejscu postawiono supermarket $\mathrm{z}$ parkingiem) oraz kościół barokowy w Anhalt, zbudowany w latach 1757-1770, który zajęła spółka bankowa ${ }^{19}$. W wielu przypadkach budynek sakralny po prostu przestaje fizycznie istnieć, na jego miejscu pojawia się zaś nowy, należący do codziennej sfery profanum, bądź pozostaje po nim symboliczna pustka. Nieco innym przykładem renowacji i symbolicznego „przywracania do życia” architektury sakralnej jest kościół św. Jana w Gdańsku, pochodzący z XIV wieku. To jeden z ostatnich zabytków miasta, który nie został odbudowany po drugiej wojnie światowej. $\mathrm{Na}$ skutek różnych decyzji dotyczących wykorzystania tego miejsca, obiekt przez kilkadziesiąt lat niszczał. W 1991 roku Skarb Państwa przekazał kościół Archidiecezji Gdańskiej Kościoła Rzymskokatolickiego, a od 1995 roku, na mocy umowy ograniczonego prawa rzeczowego użytkowania, funkcję gospodarza obiektu pełni Nadbałtyckie Centrum Kultury w Gdańsku. Głównym celem rewitalizacji dawnego kościoła jest stworzenie w tym miejscu profesjonalnego centrum kultury. Jak czytamy na stronie internetowej Trójmiasta:

Nadbałtyckie Centrum Kultury udostępniło kościół artystom i publiczności. Odbyło się tutaj wiele ważnych wydarzeń kulturalnych. Dzięki ogromnemu wysiłkowi Nadbałtyckiego Centrum Kultury, jak i innych instytucji i organizacji Pomorza, kościół stał się rozpoznawalny na kulturalnej mapie regionu, kraju i Europy. W niepowtarzalnej atmosferze wnętrza kościoła św. Jana odbyły się liczne koncerty, pokazy, przedstawienia i wystawy. (...) Centrum św. Jana zachwyca akustyką oraz wieloma możliwościami aranżacji różnych wydarzeń. Ale przede wszystkim magią tego niezwykłego miejsca, gdzie sacrum i profanum przenika się i współistnieje ${ }^{20}$.

Charakterystyczna jest tu zatem zmiana nazwy dawnego kościoła na Centrum św. Jana. Głównym założeniem prowadzonej w tym miejscu działalności kulturalnej jest bowiem wykreowanie miejsca otwartego na różnorodne projekty i przedsięwzięcia artystyczne, służącego zarówno artystom, jak i odbiorcom sztuki, w którym następuje „naturalna synchronizacja pomiędzy zachowanym dziedzictwem historyczno-kulturowym a współcze-

18 J. Kurek, Laicyzacja sacrum. Wspótczesna adaptacja świątyń do nowych funkcji, „Przestrzeń i Forma" 2011, nr 15, <http://www.pif.zut.edu.pl/pif-15_pdf/B-05_KUREK.pdf> [dostęp: 08.04.2012].

${ }^{19}$ Cyt. za: D. Karg, Określenie miejsca..., dz. cyt., s. 24 i 37.

20 <http://www.trojmiasto.pl/Kosciol-Sw-Jana, http://www.sw-jan.vn.pl> [dostęp: 17.04. 2012]. 
snością"21. Nie ma raczej wątpliwości, że tego typu działania powodują symboliczny, nawet jeżeli tylko tymczasowy, zanik sfery sacrum, zdefiniowanej powyżej jako tradycyjnie przypisanej temu miejscu. Odnajdujemy tu takie sformułowania jak „magia miejsca” czy „niepowtarzalna atmosfera”, które w tym kontekście charakteryzują po prostu miejsce przeznaczone do działań artystycznych. Jednakże, jak możemy przeczytać na stronie Centrum, sfery sacrum i profanum przenikają się i współistnieją w jednym miejscu, nadal bowiem, oprócz świeckich wydarzeń artystycznych, sprawowana jest w nim liturgia.

W przypadku ruin śmierć sacrum nie jest zatem oczywista. Opuszczone miejsce kultu, zapomniane przez człowieka i niszczejące $\mathrm{w}$ miarę upływu czasu, zmienia się w krajobraz sakralny, który jest tłem świętości lub świętością samą $\mathrm{w}$ sobie. $\mathrm{W}$ przeciwieństwie do sakralnej architektury zawiera aspekt naturalny, przyrodniczy, czyli „treści bezpośrednio pochodzące od Stwórcy", a w aspekcie kulturowym reprezentuje powszechnie zrozumiałe, uniwersalne znaczenie symboliczne ${ }^{22}$. Wszystkie ruiny, $\mathrm{w}$ tym również sakralne, po pewnym czasie zostają przecież opanowane przez naturę. Już w okresie odrodzenia ruiny były elementem kształtującym krajobraz, co, szczególnie $\mathrm{w}$ romantyzmie, zaowocowało tworzeniem pełnych nastroju obrazów podkreślających motyw vanitas, ale jednocześnie stanowiących źródło estetycznej wzniosłości. Na wątek uobecniania się wartości sakralnych poza przestrzenią miasta zwraca również uwagę Anna Grzegorczyk, gdy przypomina, że to właśnie środowisko naturalne długo było uważane za to, które $\mathrm{w}$ przeciwieństwie do miasta, zapewniało niebiański pokarm i stanowiło miejsce sacrum. Tylko bowiem w otoczeniu przyrody można, trwając w ciszy, usłyszeć "głos Boga"23. Status opuszczonej i zrujnowanej architektury sakralnej jest ambiwalentny. Opanowana przez przyrodę sytuuje się gdzieś między miejscem kulturowym a miejscem naturalnym. Jak pisze Glinkowski:

Inne oczywiście są rzeczy-miejsca naturalne, inne kulturowe. Matką pierwszych jest przyroda, a ojcem Bóg, bo jeśli nawet są dla człowieka, to nie przez niego, lecz z woli boskiej musiały się począć, a łono przyrody wydało je na świat. Z kolei miejsca kulturowe są ludzkie, aż ludzkie i tylko ludzkie, co nie znaczy, by miało brakować im boskiego tchnienia, albo miały być wyzbyte duszy ${ }^{24}$.

Jeżeli spojrzymy na ruiny architektury sakralnej właśnie z tej perspektywy, okaże się, że niekoniecznie mamy tu do czynienia z zanikiem sacrum.

$21<$ http://www.centrumswjana.pl/centrum-sw-jana> [dostęp: 17.04.2012].

${ }_{22}$ M. Swaryczewska, Sacrum i profanum w krajobrazie kulturowym. Dziedzictwo przestrzeni sakralnej na Warmii, Wydawnictwo Uniwersytetu Warmińsko-Mazurskiego, Olsztyn 2008, s. 25-27.

${ }^{23}$ A. Grzegorczyk, Uobecnianie wartości..., dz. cyt., s. 58.

${ }^{24}$ W.P. Glinkowski, Transcendencje codzienności..., dz. cyt., s. 29. 
Opuszczone miejsce kultu jest bowiem zarówno miejscem transcendentnej ciszy, jak i miejscem, w którym wartości kulturowe zostają wyparte przez naturę, która według biblijnego przekazu przywraca miejscu bożego ducha. Jak żadna inna budowla, ruina tchnie atmosferą ukojenia, szczególnie gdy dopasowuje się do otaczającego ją krajobrazu i „zrasta się z nim w jedność”, jak drzewo i kamień ${ }^{25}$. Swaryczewska podkreśla, że krajobraz naturalny również może spełnić wymagania, stawiane samym świątyniom: stanowić znak obecności Boga i świętego Ducha w danym miejscu oraz zapewnić warunki indywidualnej, a często również zbiorowej kontemplacji ${ }^{26}$. Szczególnie wtedy, gdy jeden z jego elementów stanowią ruiny budowli sakralnej. Dziko rosnąca przyroda, której elementy należą przecież do archetypów sacrum ${ }^{27}$, może stać się świadkiem milczącej obecności Boga, pojmowanego jako stwórca tego, co naturalne. Ruina architektury sakralnej zachowuje w tym wypadku „święte milczenie”, które jest ciszą wynikającą ze "śmierci miejsca”. Nie jest to jednakże cisza absolutna, lecz rozumiana jako słyszalność dźwięków natury. Przestrzeń sakralna, w tym wypadku element uświęconego krajobrazu, zachowuje swoją świętość dzięki cyklicznemu odradzaniu się przyrody, jak pisał Georg Simmel w Pejzażach Böcklina:

Cząstka natury, którą nosimy w sobie, żyje o tej porze rytmem całej natury i wraz z nią zażywa spoczynku. A przecież, owładnięci całym tym spokojem natury, czujemy zarazem wibrujące $\mathrm{w}$ nas życie (...). Wielki Pan śpi i śpimy również my, razem z nim i w $\operatorname{nim}^{28}$.

Mimo że ruina sakralna to obiekt, który uległ niszczycielskiej sile czasu, zintegrowana $\mathrm{z}$ krajobrazem wydaje się $\mathrm{w}$ pewnym sensie ponadczasowa, czy inaczej rzecz ujmując - bez-czasowa. Ten status podkreśla również Tim Edensor w Industrial Ruins, nazywając czas życia ruiny zwielokrotnioną teraźniejszością. Zrujnowana architektura nie tylko bowiem przywołuje przeszłość, lecz symbolizuje również wciąż odnawiającą się, unieruchomioną w kamieniu teraźniejszość. Spokój i swoisty bezruch, które uosabia opuszczone miejsce, kontrastują niezwykle mocno ze światem na zewnątrz, sferą profanum, gwałtownymi, społecznymi i ekonomicznymi przemianami życia codziennego ${ }^{29}$.

Zniszczony kościół - ruina sakralna bardzo często staje się szczególnym miejscem pamięci z odniesieniem do historii współczesnej, szczególnie okresu drugiej wojny światowej. Wraz z całkowitym zniszczeniem miejsca następuje swoiste zburzenie ludzkiego porządku, ruiny zaś stanowią nowy ele-

\footnotetext{
${ }^{25}$ G. Simmel, Ruina..., dz. cyt., s. 172.

${ }^{26}$ M. Swaryczewska, Sacrum i profanum..., dz. cyt., s. 47.

${ }^{27}$ Do najważniejszych zaliczyć możemy góry, drzewa, wodę i pustynię, za: tamże, s. 69.

${ }^{28}$ G. Simmel, Pejzaże Böcklina, [w:] tenże, Most i drzwi..., dz. cyt., s. 9.

29 T. Edensor, Industrial ruins..., dz. cyt., s. 125-126.
} 
ment, który przywołuje na myśl ludzką brutalność, chaos i nienormalność. Należy również zaznaczyć, że omawiane tu ruiny stanowią metaforyczny przykład śmierci gwałtownej, nieprzewidzianej, czy, jak określa ją Philip Ariès, „śmierci szkaradnej i nieprzystojnej” ${ }^{30}$. To bowiem miejsca kultu, które właściwie zniknęły z kulturowej mapy miasta nagle, w czasie jednego bombardowania, stając się jednocześnie symbolami "grozy śmierci". W takich przypadkach również pojawia się pytanie, czy wraz z symboliczną śmiercią miejsca, doświadczanego przez ludzi jako miejsce spotkania z Bogiem, utrwalania wiary poprzez liturgię i kontakt z Bożym Słowem oraz obecność kapłana, zanika sfera sacrum. Odpowiedź będzie przecząca, gdy przedefiniujemy samo pojęcie, rozszerzając, jak czyni to Mikołaj Madurowicz, jego znaczenie:

Obok bowiem czystej sfery sacrum, którą tworzą świątynie różnych wyznań i cmentarze, istnieją również quasi-sakralne strefy w sferze profanum (zeświecczone sacrum pierwszego stopnia), czyli świątki, kapliczki, krzyże przy miejskich ulicach, wyjątkowe miejsca pamięci, uświęcone krwią pojedyncze mogiły (...), miejsca zbiorowych straceń... ${ }^{31}$.

Przykład przekształcenia ruin budowli sakralnej w miejsce pamięci ofiar wojny opisuje Halina Taborska w artykule Wspótczesna sztuka publiczna w spuściźnie kulturowej miasta. W nalocie bombowym niemieckiej Luftwaffe na miasto Coventry w roku 1942 spłonęła jedna z najpiękniejszych katedr średniowiecznych. Zachowały się jedynie wieża oraz szkielet ścian zewnętrznych świątyni. Znamienna wydaje się tu próba przywrócenia tradycyjnie pojmowanego sacrum $\mathrm{w}$ tym zrujnowanym miejscu. W obrębie szkieletu murów umieszczone zostało bowiem dzieło sztuki, nawiązujące w swojej formie do chrześcijańskich przedstawień cierpiącego Jezusa Chrystusa. Jak pisze Taborska, dzieło to, wraz z inną kompozycja z brązu zatytułowaną Pojednanie:

ma razem z zachowanymi reliktami ze starej katedry, utrwalić pamięć wydarzenia i jego wagi w historii kraju; współtworzyć wizerunek miasta, które, jak wiele miast Europy, skazane zostało na zagładę i odrodziło się z gruzów; przesłać światu chrześcijańskie przesłanie - cierpienie Chrystusa i cierpienie człowieka nie powinno być zapomniane, ale wieść ku przebaczeniu i pojednaniu ${ }^{32}$.

Zdaniem autorki, $\mathrm{w}$ obrębie murów powstało w ten sposób miejsce sakralne. Pozostaje jednak pytanie, jaki status posiada to miejsce dla tych, którzy „przechodzą tędy na skróty” oraz używają ustawionych tu ławek w celu od-

$30 \mathrm{Ph}$. Ariès, Człowiek i śmierć, przeł. H. Krzeczkowski, PIW, Warszawa 1989.

${ }^{31}$ M. Madurowicz, Aksjologia największego kwartału Warszawy, [w:] A. Koseski, A. Stawarz (red.), Sfera sacrum i profanum w kulturze współczesnych miast Europy Środkowej, Warszawa-Pułtusk 2004, s. 82.

${ }^{32}$ H. Taborska, Wspótczesna sztuka publiczna w spuściźnie kulturowej miasta, [w:] E. Rewers, A. Skórzyńska (red.), Sztuka..., dz. cyt., s. 20. 
poczynku w trakcie spaceru, w drodze z pracy czy z zakupów. Może rzeczywiście jest tak, że sfera sacrum została przywrócona jedynie częściowo i tylko dla nielicznych, chociażby dla tych, którzy przychodzą tu na odprawianą raz w tygodniu „mszę pod gołym niebem”.

Znamiennie w takim kontekście brzmią słowa księdza Janusza Pasierba, który odprawiał liturgię w zrujnowanym w wyniku działań wojennych kościele Miłosierdzia Bożego przy ulicy Żytniej w Warszawie:

Pożar zarówno niszczy, jak i oczyszcza. Nędza ruin to nędza człowieka, ale poprzez pustkę po zwalonym sklepieniu przenika od góry światło, światło łaski bożej. Zwalone sklepienie przestaje chronić, ale i otwiera ${ }^{33}$.

Wypowiedź ta sugerować może próbę oswojenia materialnej śmierci sakralnego miejsca. Jak czytamy bowiem w Zapomnianej wartości śmierci, śmiertelność jest wstydliwą skazą na dumnym wizerunku człowieka. Konieczność pogodzenia się z tą niepojętą krzywdą, „metafizyczną niesprawiedliwością", wymaga podjęcia pewnego zabiegu kulturowego, który polega na "oswojeniu" śmierci przez nadanie jej rangi symbolu ${ }^{34}$. Oswojenie to dotyczyć może zatem nie tylko wytworzenia szczególnej obrzędowości, podkreślającej majestat śmierci samego człowieka, lecz również jego największych i najbardziej majestatycznych dzieł, w tym wypadku świątyni jako dzieła architektonicznego. Kościół Miłosierdzia Bożego na długi czas stał się symbolem Powstania Warszawskiego, zaś w latach stanu wojennego schronieniem dla artystów. Jak pisze Jeremi Królikowski, chociaż praktycznie nie istniał jako budynek, posiadał moc egzystencjalnego i sakralnego znaku i odsłaniał prawdę, że nawet proces przemijania miejsca, jego fizycznego upadku może prowadzić do ponownego odkrycia jego sakralnej wartości uobecniającej piękno liturgii. Przestrzeń pozbawiona dekoracji architektonicznej (co stanowi symboliczną śmierć tego miejsca $\mathrm{w}$ jego aspekcie fizycznym, materialnym) pozostała bowiem, jak twierdzi Królikowski, ta sama, gdyż zachowała swojego chrześcijańskiego ducha.

Podobne wątpliwości pojawiają się, gdy próbujemy zanalizować współczesny status ruin Charles Church w Plymouth w Wielkiej Brytanii, zbombardowanego w 1941 roku (fot. 1 i 2). Na stronie internetowej poświęconej kościołowi możemy przeczytać wspomnienia jednej z ówczesnych parafianek, panny Leigh, która, jak sama przyznaje, na wiadomość o przekształceniu kościoła w architektoniczny pomnik poświęcony ofiarom wojny miała mieszane uczucia.

${ }^{33}$ Cyt. za: J. Królikowski, Chrześcijańska interpretacja ducha miejsca, [w:] S. Bernat (red.), Niematerialne wartości krajobrazów kulturowych, Sosnowiec 2011, s. 32.

${ }^{34}$ K. Wieczorek, Zapomniana wartość śmierci, [w:] J. Kolbuszewski (red.), Problemy wspótczesnej tanatologii. Medycyna - antropologia kultury - humanistyka, Wrocław 1997, s. 18. 


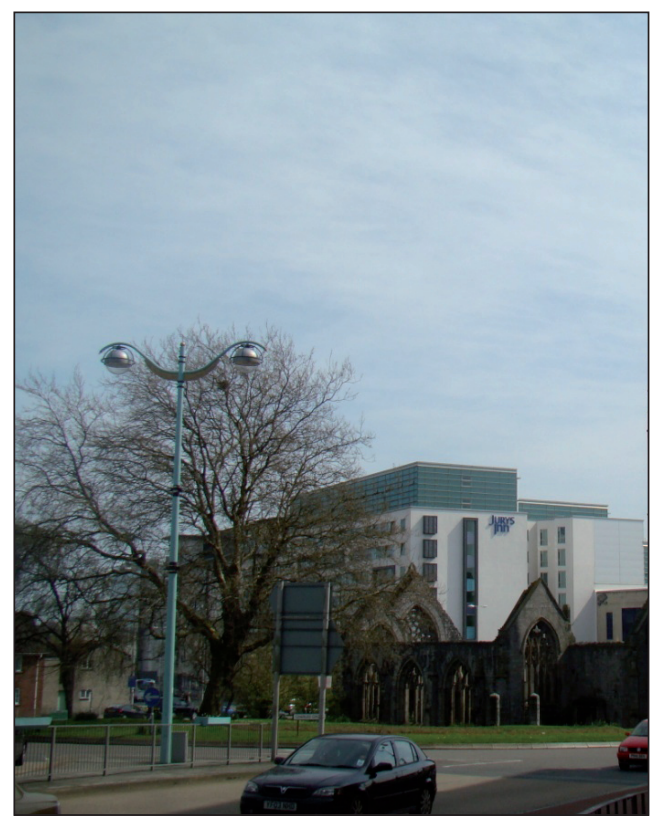

Nie wiem, co mam myśleć o idei przekształcenia kościoła w symbol upamiętniający ofiary wojennych bombardowań. Dla mnie ten kościół był miejscem cudownym, ponieważ było to miejsce, w którym poznałam Boga [podkr. M.N.]. Jego zbombardowanie w 1941 roku, jako jedne z niewielu dotychczasowych wydarzeń, wywołało moją rozpacz. Wydawało mi się, że tego dnia straciłam swoje życie ${ }^{35}$.

Ruiny tego kościoła to miejsce szczególne, które w przeciwieństwie do powyższych przykładów ruin, zdecydowanie bardziej przypomina po prostu fizyczny punkt na mapie miasta, niż miejsce doświadczane w sensie antropologicznym. Dostęp do nich utrudnio-

Fot. 1. Charles Church, Plymouth, Wielka Brytania Fot. M. Nieszczerzewska

ny jest bowiem dzięki bardzo ruchliwemu skrzyżowaniu, które $\mathrm{w}$ formie ronda otacza ze wszystkich stron zniszczony budynek. Nie posiada ono żadnego wyznaczonego miejsca dla pieszych, zatem żeby zbliżyć się do ruin $\mathrm{w}$ ciągu dnia, trzeba przebiegać pomiędzy jadącymi samochodami. Bramy ruin kościoła również są zamknięte na kłódkę. Miejsce to, w przeciwieństwie do przykładu Coventry, nie jest przeznaczone ani do odpoczynku, medytacji, ani nie stanowi elementu spacerowej ścieżki. Nie odbywa się w nim również liturgia. W latach 90. ruiny kościoła stały się przedmiotem ożywionej dyskusji

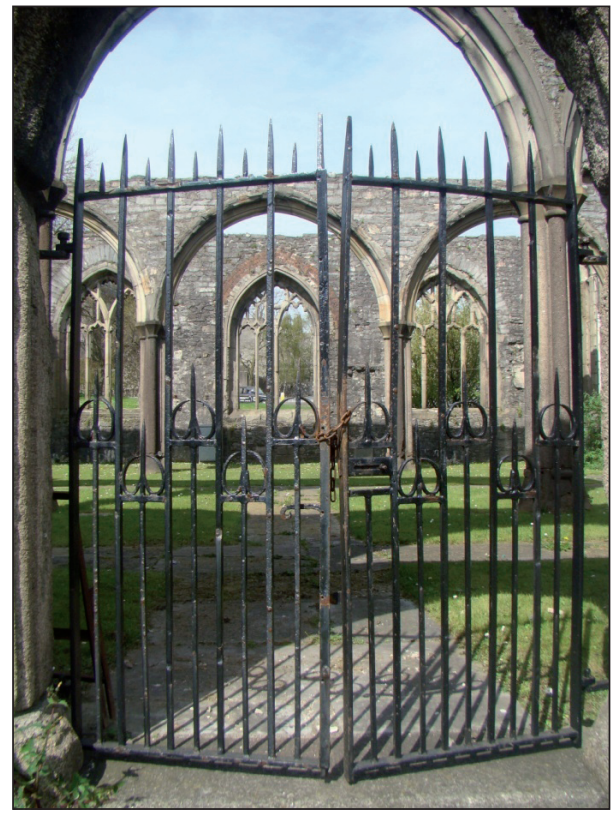

Fot. 2. Charles Church, Plymouth, Wielka Brytania

Fot. M. Nieszczerzewska

$35<$ http://www.plymouthdata.info/Churches-Anglican-Charles.htm>, <http://en.wikipedia.org/wiki/Charles_Church,_Plymouth> [dostęp: 15.04.2012]. 
dotyczącej rewitalizacji i odnowy tego miejsca, wywołanej przede wszystkim kontrowersyjnym pomysłem wybudowania w pobliżu kościoła centrum handlowego o nazwie Drake Circus oraz kampanią promującą częściowe zadaszenie ruin i przeznaczenie ich na muzeum II wojny światowej ${ }^{36}$. Usytuowanie $\mathrm{w}$ pobliżu ruin sakralnych obiektu należącego do konsumpcyjnej sfery profanum w sposób istotny przyczynia się do kolejnego etapu desakralizacji tego miejsca. Magdalena Swaryczewska nazywa ten proces degradacją krajobrazu sakralnego, który jest skutkiem przeinwestowania otoczenia, a nawet często samego miejsca kultu. Grozi to desakralizacją domu bożego, a pierwotne strefy dystansu ulegają zatarciu. Jak już zostało wspomniane powyżej, sam krajobraz (czyli w tym wypadku po prostu otoczenie ruin kościoła) także może mieć wymiar teologiczny i stanowić przestrzeń sacrum. „Nie jest zatem obojętne, czy zlokalizujemy tu parkingi i stoisko z coca-colą, czy może mistyczny ogród lub strefę kontemplacyjnej "pustki«" ${ }^{37}$. W kulturze codzienności mieszkańców Plymouth ruiny kościoła Charles Church, co jest oczywiste, odgrywają zdecydowanie mniejszą rolę niż wybudowany kilka kroków dalej shopping-mall.

Obiekty architektoniczne jako efekt ludzkiej kreatywności zdają się podlegać tym samym prawom, co ich twórcy, chociaż ich unicestwienie, jak utrzymuje Ewa Cisek, niekoniecznie musi być procesem nieodwracalnym.

Budowle począwszy od ich powstania przechodzą zwykle złożony proces niszczenia, odbudowy lub przebudowy, która prawie zawsze daje już nieco inny efekt od pierwotnego założenia, aby w końcu ulec całkowitej destrukcji. To, co dzieje się potem, może niekiedy zaskakiwać. Pierwotny obraz obiektu powraca po latach zapomnienia i niczym feniks odradzający się z popiołów ukazuje się światu jako doskonała rekonstrukcja pierwowzoru ${ }^{38}$.

Jakby na potwierdzenie powyższych słów, pierwotny, sakralny charakter kościoła w Plymouth postanowili przywrócić studenci z miejscowego uniwersytetu, rekonstruując $w$ technologii 3D stan budowli sprzed momentu zbombardowania ${ }^{39}$. W ten sposób twórcy nadają ruinom nie tylko kształt, które te dawno utraciły w wyniku niszczycielskich działań człowieka, lecz przede wszystkim przywracają im "ducha Bożego miejsca”, który metaforyzować mogą między innymi promienie słoneczne wpadające do wnętrza świątyni przez zrekonstruowane witraże. Należy jednak podkreślić,

${ }^{36}$ Centrum powstało w 2006 roku. Ruiny pozostały, jak dotychczas, w niezmienionym stanie.

${ }^{37}$ M. Swaryczewska, Sacrum i profanum..., dz. cyt., s. 41, 51.

38 E. Cisek, Norweskie katedry..., dz. cyt., s. 75.

39 Efekt tych działań możemy obejrzeć online: <http://www.youtube.com/watch?v=quSVP8QCxic\&feature=relmfu> [dostęp: 10.04.2012]; proces powstawania rekonstrukcji opisuje K. Kwiatek, <http://www.isprs.org/proceedings/XXXVIII/5-W16/pdf/kwiatek.pdf> [dostęp: 10.04.2012]. 
że rekonstrukcja obejmuje jedynie puste wnętrze świątyni, ukazane jakby w przerwie pomiędzy nabożeństwami. Ujawnia się tu zatem jednocześnie transcendentalny charakter „pustki” poprzez brak wiernych jako świadków uobecnienia sacrum.

Innym razem szczątki zapomnianej budowli mogą symbolicznie „powrócić do życia", gdy dają impuls do stworzenia całkowicie odmiennej formy architektonicznej, która pozwala na zachowanie punktowej identyfikacji przestrzeni poprzez włączanie starych reliktów do nowej struktury, również świątynnej. Przykładem takiego działania może być projekt rewitalizacji opracowany $\mathrm{w}$ pracowni architektonicznej $\mathrm{K}+\mathrm{A}$, zatytułowany Shrine over ruins ${ }^{40}$. Zakłada on, jak piszą architekci, stworzenie nowego paradygmatu zachowania dziedzictwa kulturowego poprzez adaptację czternastowiecznego kościoła katolickiego, który uległ destrukcji, do buddyjskiej świątyni. Kamienny materiał ruin został tu wykorzystany jako tło dla nowo powstającej świątyni, która ma zostać nadbudowana nad zniszczonym kościołem. Jak argumentują twórcy, idea ta wyrasta z chęci połączenia dwóch odrębnych tradycji religijnych $w$ ramach jednego obiektu sakralnego. Jeżeli jednak podtrzymamy wyjściową definicję sacrum głównie w kontekście kultu i teofanii, jego symboliczne „przywracanie do życia” również w tym wypadku wydaje się kwestią sporną. Mamy tu bowiem do czynienia z radykalnym eksperymentem, jak nazywają swój projekt twórcy, sprowadzającym chrześcijański obiekt sakralny, przestrzeń doświadczenia obecności Boga, jedynie do podstawy, nad którą dominuje nadbudowany nowy obiekt, symbolizujący religię / filozofię nie-teistyczną.

Powyższe przykłady wykorzystywania miejsca sacrum, które uległo z różnych przyczyn destrukcji, do działań artystycznych, stanowią jedynie przypomnienie, że umieranie w kulturze śmierci oswojonej stało się sztuką, swego rodzaju spektaklem, dlatego też motyw śmierci i przemijania - również symbolicznego unicestwienia architektury - jest jednym z najczęstszych motywów w sztuce. Szczególną próbę przywracania ruinom utraconego sacrum odnaleźć możemy nie tylko w ramach działań artystycznych odbywających się wewnątrz zrujnowanej budowli, tworzenia trójwymiarowych rekonstrukcji cyfrowych, czy nowych projektów świątyń różnych wyznań, lecz również $w$ muzyce, gdzie tematyka ruin stanowi inspirację dla stworzenia niezwykłej przestrzeni akustycznej. Jak pisze Ewa Klima, przestrzeń sacrum to przestrzeń wypełniona zarówno ciszą, jak i dźwiękiem ${ }^{41}$, który pomaga

${ }^{40}$ Opis projektu i fotografie na stronie: <http:/ / www.kolodziejarchitekci.pl/index.php?/ projects/shrine-over-ruins> [dostęp: 15.04.2012].

${ }^{41}$ E. Klima, Dźwięki i cisza jako składowe przestrzeni sacrum, [w:] S. Bernat (red.), Dźwięk w krajobrazie jako przedmiot badań interdyscyplinarnych, Instytut Nauk o Ziemi UMCS, Lublin 2008, s. 173. 
zrozumieć miejsce, ułatwia orientację oraz ożywia ją. Twórcy przynależący do nurtów takich jak dark ambient wykorzystują motyw opuszczonych miejsc i przestrzeni, w tym również miejsc sakralnych, komponując swoiste pejzaże dźwiękowe (soundscape art) ${ }^{42}$. Pejzaż dźwiękowy wymaga widocznej zmiany pozycji związanej z percepcją opuszczonego miejsca sacrum. Z obserwatora lokującego się wobec pozostałości budynku lub obrazu ruiny, odbiorca staje się uczestnikiem, który w przenośnym sensie wkracza w krajobraz sakralny, porzucając spojrzenie panoramiczne na rzecz $\mathrm{w}$ pełni zmysłowego zaangażowania ${ }^{43}$. Pojawia się tu zatem kwestia „wewnętrzności” i ,zewnętrzności”, centralna dla filozofii miejsca. W środowisku akustycznym jesteśmy bowiem $\mathrm{w}$ pewnym sensie zanurzeni, odbieramy pełną panoramę otaczających nas dźwięków, które tworzą szczególną scenografię. Nie bez powodu jeden z czołowych twórców dark ambientu, Peter Andersson, nazywa siebie sound designer. Szczególna atmosfera zapomnianych i opuszczonych budynków sakralnych, ich genius loci, jest w tym wypadku kreowane w ramach przywoływania dźwięków dzwonów kościelnych, ludzkich głosów - elementy śpiewów chóralnych, którym towarzyszą różne linie melodyczne i dźwięki przyrody "otaczające" odbiorcę tych muzycznych wyobrażeń. Szczególnie dźwięk kościelnych dzwonów jest tym, który nieodmiennie kojarzy się odbiorcy z chrześcijańską sferą sacrum. Warto zatem w tym miejscu podkreślić symboliczną wieloznaczność tego dźwięku:

Obok funkcji liturgicznych (akcentowanie najważniejszych momentów mszy św., nawoływanie do modlitwy "Anioł Pański” i w intencji pokoju) dzwony, podobnie jak zegar, porządkowały życie miasta, wyznaczały rytm życia ludzkiego, obwieszczały otwarcie i zamknięcie bram miejskich, czas trwania targu, wyznaczały porę ciszy nocnej. Dzwony biły także na trwogę (np. wzywając mieszczan pod broń lub do gaszenia pożaru). W zamierzchłych czasach dzwony odstraszały duchy, czarownice, burze (...). Do obecnego stulecia odgłos dzwonów [symbol trwałości, bogactwa i potęgi - również sacrum, przyp. -M.N.] był najdonioślejszym dźwiękiem słuchanym przez społeczność. (...) wydaje się, że obecnie mimo prób nie został on zastąpiony niczym innym ${ }^{44}$.

Nawet gdy przestrzeń święta uległa zniszczeniu, dźwięk dzwonów jest tym, który nieodmiennie kojarzy się ze sferą sacrum. Świadczy o tym chociażby przypadek rumuńskiego cmentarza w Sapancie, w którym naprzeciwko wejścia do odrestaurowywanego zrujnowanego kościoła cmentarnego umieszczono drewnianą konstrukcję eksponującą odnowione dzwony tego

${ }^{42} \mathrm{Na}$ temat krajobrazu dźwiękowego zob. A. Nacher, Sto tysięcy miliardów dźwięków. Podróż poza wzrokocentryzm (pejzaż dźwiękowy, soundwalk, aural safari), „Kultura Współczesna” 2010, nr 3.

43 Por. B. Frydryczak, Na tonie natury: od krajobrazu do naturalnego środowiska turystycznego, „Kultura Współczesna” 2010, nr 3, s. 100.

${ }^{44}$ S. Bernat, Krajobraz dźwiękowy jutra, [w:] tenże (red.), Niematerialne wartości..., dz. cyt., s. 194. 


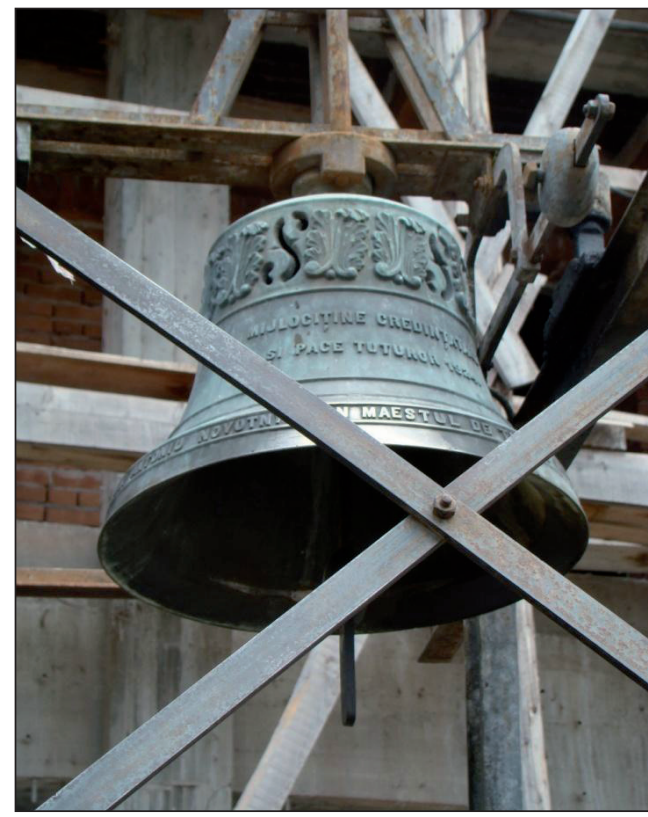

Fot. 3. Wesoły Cmentarz, Sapanta, Rumunia, Fot. M. Nieszczerzewska

kościoła (fot. 3). Można je potraktować jako chwilowo niemy symbol zniszczonego miejsca świętego, który jednakże zapowiada metaforyczny i fizyczny "powrót do życia" całego obiektu.

Krajobraz dźwiękowy dostarcza całkowitej zmiany percepcji i doświadczenia sakralnych ruin. Wprowadzane dźwięki, niegdyś codziennie obecne $\mathrm{w}$ danym miejscu, służą ponownemu ożywieniu sfery sacrum w budynkach, które odeszły już do przeszłości ${ }^{45}$. To symboliczne przywracanie do życia dokonuje się zatem dzięki szczególnym, muzycznym "opowieściom" o bezwzględnej i destruktywnej sile czasu, zapomnianych miejscach i ruinach opanowanych przez naturę. Poszczególne „dźwięki zaklęte w kamieniu" wywołują w odbiorcy przede wszystkim doświadczenie konkretnych uczuć i emocji: zagubienia, samotności, pustki, smutku, nostalgii, melancholii, tęsknoty czy lęku. Odczucia te, oprócz dźwięków, wywołuje również strona tekstowa, czyli nazwy muzycznych projektów i tytuły poszczególnych utworów. Wystarczy wymienić kilka z nich: In Sadness, Silence and Solitude, Songs Over Ruins, Inner Depths of Sadness, In Absence of Light, Mesmerized in Sorrow. Jak sugeruja przywołane tytuły, wkraczamy tu jednocześnie w sferę samotności, której miarą nie jest jedynie fizyczne odosobnienie opuszczonych miejsc, ale pewna kontekstowa niezależność ich bytowania.

W przeciwieństwie do konkretnych budynków wspomnianych powyżej, mamy tu do czynienia z metaforycznym, ogólnym wyobrażeniem ruin, niekonkretnych i nienazwanych. Jak pisze bowiem Tadeusz Sławek,

Genius loci bez wątpienia odnosi nas do miejsca, ale jednocześnie odkrywa to, że miejsce owo zawdzięcza swoją wartość temu, co je przerasta, co rezydując w nim, każe mu nieustannie wykraczać poza przypisane miejscu ograniczenia ${ }^{46}$.

${ }^{45}$ Można wymienić tu projekty takich artystów jak Johan Levin (Desiderii Marginis), Ulf Söderberg (Sephiroth), Rafał Sądej (Moan), czy wspomniany już Peter Andersson (Raison d'être).

${ }^{46}$ T. Sławek, Bowman, opodal farmy Chapmana, nad Bear River, [w:] Z. Kadłubek (red.), Genius loci..., dz. cyt., s. 141-144. 
W projektach muzycznych, o których tutaj mowa, dźwiękom towarzyszą również obrazy, zamieszczone na okładkach wydawanych płyt i stronach internetowych poświęconych poszczególnym projektom. Stanowią one dodatkowy element, który stymuluje wyobraźnię odbiorcy i kreuje atmosferę miejsca. To dopełnienie jest niezwykle istotne, bowiem wyobrażenie miejsca, jakie kryje się pod konkretnym soundscape, oddziałuje w każdym wypadku na wyobraźnię wizualną odbiorcy pejzażu akustycznego i ewokuje kolejne wyobrażenia. Wizualne techniki reprezentacji stają się zatem w tej sytuacji narzędziami, dzięki którym zamknięty w ramach kadru i gotowy do wizualnej konsumpcji obraz ruin, ogrywa rolę pewnego artefaktu dopełniającego akustyczne doświadczenie muzycznego spektaklu. Pejzaż dźwiękowy ilustruje w tym wypadku wyobraźniowe wizualizacje ruin, podobne do tych, które odnajdujemy na obrazach Caspara D. Friedricha ${ }^{47}$.

W wyobrażeniach muzycznych również odnajdujemy motyw antropomorfizacji ruiny i opuszczonego miejsca. Świadczą o tym chociażby takie tytuły jak Souls Lost, Requiem for Abandoned Souls, The Spirit will not share the Guilt czy Death in the Body, but made alive in the Spirit. Fizykalny byt architektury sakralnej być może należy już do przeszłości, pozostał jednakże „duch", który ten byt może znów ożywić. W tych wyobrażeniach ruiny są miejscami opuszczonymi przez ludzi, jednak, parafrazując tytuł artykułu Tadeusza Sławka ${ }^{48}$, nie przez Boga. Muzyczne projekty mogą zatem stanowić próbę uchwycenia i oddania wymiaru sakralnego kamienia jako szczególnej pozostałości po miejscu kultu i zbiorowym oraz indywidualnym doświadczeniu religijnym.

Widzimy zatem, że przestrzeń nie tyle „jest”, ile, być może, w danym momencie "staje się" święta dzięki różnym praktykom odtwarzania znaczeń jej przypisanych, zanika i „umiera” zatem wtedy, gdy tych znaczeń brakuje. Powyższe przykłady potwierdzają słowa autorki Przeklętego sacrum, która lokuje to pojęcie w obrębie kategorii odczućt9. Można się zatem zgodzić, że sacrum obecne w ruinie, Simmlowskim „miejscu, które życie już opuściło”, jest kategorią ukrytą, dostępną jedynie dla wtajemniczonych, która objawia się nie tylko poprzez przestrzeń, ale również, a może przede wszystkim poprzez czas. Jakby wbrew twierdzeniu Vladimira Jankélévitcha, że ogólnie rzecz ujmując nie mówi się raczej o „metafizyce” śmierci, zaś wiele uwagi poświęca się jej "fizykalności” ${ }^{50}$, problem ruiny sakralnej jako „śmierci miejsca” zakłada jednak myślenie o metafizyce tego procesu. Chociaż wyburzanie zniszczonych

\footnotetext{
${ }^{47}$ Więcej na ten temat zob. M. Nieszczerzewska, Wyobrażenia opuszczonych miejsc, w druku.

48 T. Sławek, Miasto zapomniane..., dz. cyt., s. 67.

49 B. Kietlińska, Przeklęte sacrum..., dz. cyt., s. 251.

${ }^{50}$ V. Jankélévitch, Tajemnica śmierci i zjawisko śmierci, [w:] Antropologia śmierci..., dz. cyt.,
} s. $43-44$. 
i opuszczonych kościołów lub adaptowanie ich na cele świeckie powoduje banalizowanie myślenia o "śmierci miejsca świętego", to powyższe przykłady, wybrane z wielu im podobnych, potwierdzają, że samoistność sacrum jako tajemnicy o wymiarach wykraczających poza codzienne doświadczenie, raczej nie daje się zastąpić niczym innym.

\section{The ruins of sacral architecture. The death of a place - the death of sacredness?}

\section{Sum mary}

The main topic of the article is sacred, but abandoned, derelict and forgotten places. The author pays particular attention to the issue of an ontological status of a sacred ruin as a non-place and the issue of the disappearing sacredness which once defined abandoned architecture. A ruin is designated a non-place as a result of a phenomenological definition of a place as a point in space with a particular identity. The author tries to answer the question of whether sacral architecture can still function as a place after it has been abandoned and is no longer present in the experience of ordinary people. 